\title{
Ways of Independent Development of Pedagogical Competencies of Students in Innovative Activity (The Study Case of Azerbaijani Students in Mathematics and Computer Sciences)
}

\author{
Mehriban Hasanova \\ Department of Informatics, Ganja State University, Azerbaijan Republic \\ Received June 2, 2020; Revised July 16, 2020; Accepted August 10, 2020
}

\section{Cite This Paper in the following Citation Styles}

(a): [1] Mehriban Hasanova, "Ways of Independent Development of Pedagogical Competencies of Students in Innovative Activity (The Study Case of Azerbaijani Students in Mathematics and Computer Sciences), "Universal Journal of Educational Research, Vol. 8, No. 9, pp. 4143-4150, 2020. DOI: 10.13189/ujer.2020.080940.

(b): Mehriban Hasanova (2020). Ways of Independent Development of Pedagogical Competencies of Students in Innovative Activity (The Study Case of Azerbaijani Students in Mathematics and Computer Sciences). Universal Journal of Educational Research, 8(9), 4143-4150. DOI: 10.13189/ujer.2020.080940.

Copyright $(2020$ by authors, all rights reserved. Authors agree that this article remains permanently open access under the terms of the Creative Commons Attribution License 4.0 International License

\begin{abstract}
Regular innovations in the field of learning technologies are being implemented with the aim of removing educational problems, flexible steps are taken to organize the learning process, and the content and methods of teaching are improved. The research highlights the main problems faced by Azerbaijani education and describes the author's methodological system that searches for their solutions. The purpose of the experiment was to develop the theoretical foundations for independent development of students' pedagogical competencies in the process of innovative activity and to exclude them from experimental verification. Initially, the working hypothesis of the study was formulated, favorable conditions for carrying out the experiment and universities to be experimented with were identified, and computerization was studied in two higher education institutions of the republic. Experimental and control groups were selected, in certain groups approximate equality of the students and the teachers' levels were provided, and the levels of the groups were learned in written and oral ways. Analysis of the results of the experiment has shown that the developed concept can be used in training pre-service and in-service teachers studying mathematics and computer science as it can improve the effectiveness of teaching in innovative activity.
\end{abstract}

Keywords Azerbaijani Education, Computer
Technologies, Pedagogical Conditions, Competencies, Pedagogical Experiment, Innovative Activity

\section{Introduction}

The modern society continues to introduce new requirements to improve the development of the education system. Azerbaijani education is changing its content and form as the part of the global education system to bring the level of our education in line with international standards. However, our education system faces certain problems that negatively affect the relationship between education and life.

One of the main problems in our education system is providing the students not with practical work, but with theoretical knowledge. The lack of proper supply plays a more serious role. In this view, our education system differs from the education system of many European countries, including Finland. The main direction of the Finnish education system is a wide range of practical exercises. Unlike theoretical engagement, practical engagement is more interesting and more attractive. It connects the student to the training process, automatically distracting his/her attention from all extraneous work. 
Problem-oriented education differs by its own innovative training methods. This training is accompanied by such activities as discussion, joint activity in groups, and independent research of information. Unfortunately, authoritarian methods are still used in training in many higher schools.

One of the problems with our education is that there is no pedagogical potential for the introduction of new technologies in the learning process and, therefore, the process is not interesting for both educators and students. The main problem is not seeing what benefits will be obtained from the knowledge gained, and therefore the important stimulus for learning is lacking.

The application of computer-aided technologies is considered necessary and important by students of higher schools in the pedagogical activity process. In this regard, applied and instrumental programs are used for developing information competencies in the process of assimilation of the educational program [1]. It is known that the most commonly used materials related to the characteristics of the applied programs are taught both at secondary and higher schools $[2,3,4,5]$. This repetition and monotony lead to a decrease in interest of students and schoolchildren in learning applied programs. Therefore, it is necessary to change the nature and purpose of the task, as well as to realize the solution to problems of the same nature through various applied programs. This will develop the planned and purposeful problems and improve the consecutive thinking ability of students [5].

It is clear that the shown characteristics are formed as a result of the teacher's innovative activity. The teacher must be able to develop his/her competencies during such innovative activity. This formation should take place at education institutions, with pedagogical conditions established [6].

The author believes that it is possible to develop independently the pedagogical competencies of students in an effective way under the following conditions (hypothesis):

- it is necessary to take into account the interests and difficulties of the students in the innovative pedagogical activity of the teacher;

- to analyze and systematize the tasks the teacher faces during the innovative activity;

- to take into account the actual and potential level of pedagogical competencies of students;

- to identify existing barriers and factors for independent development of pedagogical competencies of students;

- to use the 10-point diagnostic methodology in the pedagogical experiment to evaluate the pedagogical competencies of students.

In order to overcome the problems mentioned above, there are constant innovations in the field of learning technologies, flexible steps are taken to organize the learning process, and the content and methods of teaching are improved [7, 8, 9, 10,11, 12, 13].

As the article deals with the research aimed at solving these problems, its relevance is clear. The aim of the research is to develop the theoretical foundations for independent development of students' pedagogical competencies in the process of innovative activity and to exclude them from experimental verification.

On the basis of the assumption it is necessary to perform a number of interrelated tasks:

1. Theoretically justify the essence of the independent development of students' pedagogical competencies during innovative activities.

2. Experimentally test the effectiveness of complex pedagogical conditions for independent development of students' pedagogical competencies.

3. To set tasks for independent development of pedagogical competencies of students in the process of innovative activity.

\section{Methodology and Results}

The complex research method was used to successfully complete the research. The three-stage pedagogical experiment was conducted to prove the hypothesis from 2017 to 2019.

The first stage (2017) was called the initial stage of empirical and theoretical search. The aim of the study was to develop new ways and methods to increase the competency of students, the essence of the problem, and study the problem situation in school practice, determine theoretical and methodological basics of solving the proposed problem. Initially, the working hypothesis of the study was formulated and expressed; there were determined conditions for carrying out the experiment and the universities in which the experiment was conducted. A pedagogical experiment in mathematics and computer science was planned to be carried out in two higher educational institutions of the republic: Ganja State University (Ganja, Republic of Azerbaijan) and Azerbaijan State Pedagogical University (Baku, Republic of Azerbaijan).

Computerization was studied at the both universities, and experimental groups were selected after observing the studies in the second half of the school year. These groups attended computer science lessons, which allowed observing the students' activity; written and oral exams were conducted with them. Analysis of the students' results shows that the vast majority of students prefer to use new information technologies. In these groups, a questionnaire was conducted among teachers of computer science. According to the survey, teachers are trying to use new teaching technologies and active teaching methods (European, interactive, etc.) in the learning process. Nevertheless, a large number of students encounter difficulties in mastering programming elements, are not able to apply the acquired knowledge to specific tasks, and 
there are gaps in the knowledge and skills of students. During the pedagogical experiment, the gaps in the study of programming elements were eliminated, as well as the knowledge and skills of students, the difficulties they encountered. Corrections were made to the content of training and the choice of teaching methods.

After initial testing, the experimental and control groups were clearly identified and were expected to have approximately equal levels of students and teachers in the study area.

Programs, textbooks, curricula, and ICT tools were used at the second stage of a pedagogical experiment called "Teacher" (academic year 2017/2018). There were applied new methods of teaching mathematics and computer science at the Faculty of Mathematics. Research work was carried out to study and implement the developed methodological system. Thus, the developed methodology for using ICT tools enabled to enhance students' competencies, familiarizing teachers of experimental groups with the same content and methodology, as well as conducting a training experiment on a new system developed in experimental groups.

With the help of ICT tools, efforts have been made to develop the necessary working skills of teachers and students. Thus, for training experimental groups to use the methodology, an approximate scenario of classes in various subjects was developed, which was distributed among subject teachers who participated in the experiment. The goals and objectives of the experiment were explained to them. During the experiment, the suggestions, recommendations, and notes of the teachers were also carefully studied and taken into account by those who served the ideas of the study. The teachers were timely acquainted with practical exercises.

Textbooks and teaching aids in mathematics and computer science allowed selecting most of the tasks employed both in model applications and in curricula. They were used in sample lesson scenarios with creative tasks and examples of their implementation. There was developed a program to show how to use the scenarios to solve mathematical problems. For example, computer science specialists, who studied $\mathrm{C}++$ programming languages, learned about types of variables and an input operator, and examples of how to use mathematical problems were shown in training.

\section{Structure of the Lesson}

- Organization of the initial stage of the lesson.

- Comparative assimilation of mathematical and informative meanings of the notion of variables among students.

- Adapting students to use variables both in mathematical form and in programming.

- Providing the order to establish a simple program with variables and constants.
The children are instructed to draw simple figures on the workplace by giving different commands in $\mathrm{C}++$ programming environment at the phase of activity of the lesson. Then, they are given a task to find the regularity in the following mathematical expressions and to replace three expressions with a common mathematical expression:

$$
15 * 4+7 \quad 15 * 8+7 \quad 15 * 12+7
$$

Thus, the result is discussed, the students are asked such questions as "Which numbers did you replace with variables?", "Why". Then, the teacher comments on the following content:

- While executing the program, the value-changing quantities are called variables, the quantities which values are not changed are called constants. Every variable has a name. These names coincide with the commands' names. All variables used in the program are declared in advance.

- The types of the main variables will be learned under 4 subtitles including full, real, symbol and line data types in $\mathrm{C}++$.

The full data type is a type able to save the numerical data. There are some data types. The biggest difference between them is the number of elements to be saved. For instance, float type can save up to half of the double type. That is, float type saves 32 bytes, while double type has 64 bytes. However, this difference has some advantages.

As an example, we can state that while performing operation between figures from 1 to 10 in one problem, in another problem, the operation is performed between $1,000,000$ and $5,000,000$. If we use the same type of variable in both problems, we will save unnecessary space in the first problem.

A byte memory is allocated for Char variable type. It has the same nature as the real type. However, each included number is combined with the equivalent number in Unicode.

int main ()

$\{$ char herf $=$ ' $K$ ';

char herf $2=65 ;\}$

Though that letter $\mathrm{K}$ is written in the place allocated for the above-mentioned letter, the equivalent number of letter $\mathrm{K}$ in Unicode is given at the background.

2 bytes memory is allocated for Short variable type. Total numbers are written inside. Short type ranges between $-32768-32767$.

int main ()

\{ short Tam eded = 55;

INT type: is the abridged form of the word "Integer" and 4 bytes memory is allocated for int type. It is commonly used variable type for numbers in programming. Int type ranges between $2147483648-2147483647$. 
public static void main (String $\{$ args)

$\{$ int tam eded $=2013$; $\}$

LONG type: Long variable type is not used much in $\mathrm{C}++$, as it is complex. However, in Java, long variable type saves the interval not saved by integer type. 8 bytes memory is allocated for Long variable type. The value range of this type is between $-2^{63}$ and $2^{63}$.

public static void main (String \{\} args)

\{ long uzunTam eded $=2000000000$;

REAL TYPE: In real type, we can use dotted numbers (fraction numbers). Two real number types used in $\mathrm{C}++$ double and float variable types have passed to Java language as is and coincide with their borders.

4 bytes memory is allocated for float variable type. It can save 7 cells. Float type ranges between-3.4 x $10^{38}$ and 3.4 $\times 10^{38}$

public static void main (String \{\} args)

$\{$ float normalistifade $=4745.96 \mathrm{~F}$;

float Standartistifade $=47 E 4 F ; \quad\}$

8 bytes memory is allocated for Double variable type and it can save up to 15 cells. Therefore, when the part after comma is greater than 7, double type is preferred instead of float variable type. The value range for Double type is between $-1.7 \times 10^{308}$-and $1.7 \times 10^{308}$.

public static void main (String [] args)

$\{$ double normalistifade $=960.7744485102$; double Standartistifade $=96 E 41 ; \quad$ \}

Line types are variable types that allow the use of symbols other than numbers. As in $\mathrm{C}++, 2$ variable types, including string and boolean will be talked about in this section.

8 bytes memory is allocated for String type. String variable type not recognized in $\mathrm{C}$ and added later in $\mathrm{C}++$ was created in classes in Java. As in the object-based issues, no detailed study will be conducted on class notion.

1 byte memory is allocated in Java for Boolean variable type just like in $\mathrm{C}++$ and they are used to check the results of the logical problems. As it works on byte, only true and false values can be obtained.

\section{public static void (String \{\} args) \\ $\{$ boolean dogruQerar $=$ true; \\ boolean yalnisQerar $=$ false; \\ boolean qerar $1=(10>4)$; \\ boolean qerar $2=(10<4) ; \quad\}$}

Each programming language has its own library. The main purpose of describing libraries is to avoid repetitive writing of frequently used elements such as functional, macro, and variable types, to store them together and call when used.

As at the beginning of the programming languages, there are also libraries added later. Thanks to day by day advanced technology, we can find all of these libraries on the internet.

INPUT OPERATORS: Initial data are often needed in programming. The initial data can be any file or any data to be transferred from devices such as USB, as well as a letter or number to be entered from the keyboard. We can see different ways of retrieving information from the keyboard, formatting them and working out for Java and $\mathrm{C}++$ languages in the subtitle.

Iostream library is addressed for using cin and cout operators in $\mathrm{C}++$. At the same time, cin and cout operators are noted together with $s t d$. General writing is as following: std : : cout

It is necessary to add the following code to the library advertisement section to simplify the writing form.

Using namespace std;

The announcement of this library makes the writing of the program simpler, as we do not have to add std in front of cin and cout operators every time we announce this library.

Generally speaking, the announcement of the library can be written as following in $\mathrm{C}++$ program:

\#include $<$ iostream $>$

using namespace std;

Input operators in $\mathrm{C}++$ : Although there are several input operators in $\mathrm{C}++$, we will learn about cin operator used more in $\mathrm{C}++$. The word "cin" is an abbreviated form of the word " $C++I N$ " and is used in conjunction with operator $\gg$. cin operator is the main input operator in $\mathrm{C}++$ language.

The general writing form is the following:

cin $>>$ deyişen;

cin $>>$ deyişen $1>>$ deyişen $2>>\ldots>$ deyişen $N$;

The biggest advantage of $\mathrm{cin}$ operator is that it conducts formatting itself. scanf function used for $\mathrm{C}$ language can have a different format for other types of variables. But cin operator used in $\mathrm{C}++$ language operates this format itself. It eliminates the dependence of input codes on variable types in the program and minimizes the error as a result of modifications we make in the program.

We can write the following program code as an example: \#include $<$ iostream $>$

using namespace std;

int main()

\{ int tameded;

double Onluqkesr ;

string soz ardicilligi;

cin $>>$ tameded;

cin $>>$ Onluqkesr

cin $>>$ soz ardicilligi; $\}$

Using this program, we can add algorithm " 15 [ENTER] 50.875 [ENTER]" from the keyboard. General writing form will be as follows:

Tam eded: 15

Onluq kesr : 50.875

soz ardicilligi: algoritm

... qiymatlarini almış olacaq.

CIN.GET- Only one line of text input from the keyboard can be read. Regardless of the length of the data, get operator simply focuses on the first cell and accepts it as char type.

Generally, the structure of cin.get operator is as 
following:

cin.get (DӘYIŞつN) ;

Let's consider the following program model:

\#include $<$ iostream $>$

using namespace std;

int main ()

$\{\operatorname{char} x$;

cin.get $(x) ;$ \}

When the abovementioned program is launched, it will first wait for the information and at this time it will simply get the digit of the first cell, even if it is an input word or digit. This value will be replaced by variable $x$ previously announced as char.

At the end, students are instructed to set up a simple mathematical problem, a program for calculating the area of a triangle in order to strengthen their knowledge.

The text of the program is defined together with students. Then, the teacher runs the computers and solves the problem together with students. They are asked to solve the problem at different sizes of the sides and parameters of the triangle. It is explained that there is no need to set up a program every time when solving this problem in different parameters and sizes. Therefore, it is necessary to replace the value of the variable. Then, students can be instructed to solve the problem by changing the nature of the problems in groups. For example, setting up a program for calculating the areas of different figures and so on:

1) Set up a program for calculating the area of rectangle.

2) Set up a program for calculating the length of circle.

3) Set up a program for calculating the area of trapezium.

4) Set up a program for calculating the area of circle.

At the next stage of the lesson, the teacher summarizes the results and makes analysis and correction of general characteristical mistakes. Students' evaluation levels are also built on this type of work. Then the teacher sums up the lesson.

Thus, the training of the research ideas was implemented in experimental groups; the control groups worked in the traditional way. In the experimental groups, we sought to create conditions for all stages of training in accordance with the ideas of the study, so that students can perform the task of overcoming difficulties in independent activity of thinking. This develops students' ability to function, independence, determination, and achievement of the set goal. It helps independently analyze and compare, generalize, draw conclusions and judge.

In the experimental groups, students observed an interest in discovering, studying, and understanding new ones, as well as an interest in applying the acquired knowledge to solve practical problems. They showed their intellectual activity, initiative and desire to achieve the goal, the formation of emotional and volitional qualities, to overcome difficulties.

The third stage of the pedagogical experiment was called the controller (academic year 2018/2019). The material of the program involved in the experiment was studied, and after completing the study the test material was identified. Both the experimental and control groups were provided with systematic exercises, final tests were given to determine the acquired mathematical knowledge on the topic. The training material was based on answers to control and oral questions, the necessary adjustments were made.

At the first stage of the experiment, five interim checks were performed, and their results were checked and analyzed (table 1, table 2 and figure 1). Finally, a final inspection was conducted and the result was analyzed. The results obtained at each stage of the pedagogical experiment were analyzed using statistical methods. Statistical analysis of the results was carried out in the following way: The first test results are the results of the first test - K1, the results of the second control $-\mathrm{K}_{2}$, and so on. We named the final result $\mathrm{Ky}$. The $\mathrm{K}$-scores indicate the proportion of test results with the results of each experiment. We also calculated the average grade for school enrollment as the average of the grade point average.

Table 1. Results of the initial control

\begin{tabular}{|c|c|c|c|c|c|c|c|c|c|}
\hline \multirow[b]{2}{*}{ Universities } & \multirow[b]{2}{*}{ Groups } & \multirow{2}{*}{$\begin{array}{c}\text { Number } \\
\text { of } \\
\text { students }\end{array}$} & \multicolumn{4}{|c|}{ Values } & \multirow[b]{2}{*}{$\mathrm{A}$ and $\mathrm{B}$ in $\%$} & \multirow{2}{*}{$\begin{array}{l}\text { Assimilation during } \\
\text { control in } \%\end{array}$} & \multirow{2}{*}{$\begin{array}{c}\text { Numerical } \\
\text { average value }\end{array}$} \\
\hline & & & A & $\mathrm{B}$ & $\mathrm{C}$ & $\mathrm{D}$ & & & \\
\hline \multirow{6}{*}{ ASPU } & Experimental -RI201 & 25 & 4 & 5 & 8 & 8 & 36 & 68 & 3,2 \\
\hline & Control -RI202 & 24 & 5 & 6 & 6 & 7 & 46 & 71 & 3,38 \\
\hline & Experimental -I201 & 21 & 3 & 5 & 8 & 5 & 38 & 76 & 3,28 \\
\hline & Control -I202 & 20 & 3 & 7 & 6 & 4 & 50 & 80 & 3,45 \\
\hline & Experimental -I301 & 20 & 4 & 7 & 5 & 4 & 55 & 80 & 3,55 \\
\hline & Control -I302 & 24 & 5 & 8 & 9 & 2 & 54 & 92 & 3,66 \\
\hline \multirow{6}{*}{ GSU } & Experimental -RI- $2^{1}$ & 33 & 6 & 8 & 8 & 11 & 42 & 67 & 3,27 \\
\hline & Control -RI-2 ${ }^{2}$ & 22 & 3 & 6 & 8 & 5 & 41 & 77 & 3,31 \\
\hline & Experimental -IM-1 ${ }^{1}$ & 39 & 7 & 9 & 15 & 8 & 41 & 79 & 3,38 \\
\hline & Control -IM-1 ${ }^{2}$ & 19 & 4 & 4 & 8 & 3 & 42 & 84 & 3,47 \\
\hline & Experimental $-2^{2}$ & 28 & 4 & 9 & 7 & 8 & 46 & 71 & 3,32 \\
\hline & Control -IM-2 ${ }^{1}$ & 25 & 4 & 8 & 7 & 6 & 48 & 76 & 3,4 \\
\hline
\end{tabular}


Where,

$$
\begin{aligned}
& \left.\mathrm{K}_{\mathrm{i}} \text { (in the initial control) }\right)=\frac{\text { numerical average value of the experimental group }}{\text { numerical average value of the control group }} \\
& \left.\mathrm{K}_{1} \text { (in the first control }\right)=\frac{\text { numerical average value of the experimental group }}{\text { numerical average value of the control group }} \\
& \left.\mathrm{K}_{2} \text { (in the second control }\right)=\frac{\text { numerical average value of the experimental group }}{\text { numerical average value of the control group }} \\
& \mathrm{K}_{\mathrm{y}}(\text { in the final control })=\frac{\text { numerical average value of the experimental group }}{\text { numerical average value of the control group }}
\end{aligned}
$$

\begin{tabular}{|c|c|c|c|c|c|c|c|c|}
\hline Universities & Groups & N.A.V. initial & N.A.V. 1 & N.A.V. 2 & N.A.V. 3 & N.A.V. 4 & N.A.V. 5 & N.A.V. Total \\
\hline \multirow{6}{*}{ ASPU } & Experimental -Rİ201 & 3,2 & 3,34 & 3,56 & 3,7 & 3,7 & 3,78 & 3,8 \\
\hline & Control-RI202 & 3,38 & 3,5 & 3,54 & 3,52 & 3,4 & 3,54 & 3,4 \\
\hline & Experimental -I201 & 3,28 & 3,32 & 3,38 & 3,75 & 3,72 & 3,78 & 3,8 \\
\hline & Control -I-202 & 3,45 & 3,3 & 3,55 & 3,45 & 3,45 & 3,2 & 3,55 \\
\hline & Experimental-I301 & 3,55 & 3,56 & 3,56 & 3,7 & 3,78 & 3,7 & 3,85 \\
\hline & Control -I-302 & 3,66 & 3,45 & 3,33 & 3,69 & 3,46 & 3,5 & 3,42 \\
\hline \multirow{6}{*}{ GSU } & Experimental -RI-21 & 3,27 & 3,24 & 3,45 & 3,39 & 3,81 & 3,54 & 3,7 \\
\hline & Control -RI-2 ${ }^{2}$ & 3,31 & 3,23 & 3,55 & 3,36 & 3,36 & 3,27 & 3,3 \\
\hline & Experimental -IM- $1^{1}$ & 3,38 & 3,4 & 3,53 & 3,58 & 3,69 & 3,68 & 3,95 \\
\hline & Control -IM-1 ${ }^{2}$ & 3,47 & 3,47 & 3,5 & 3,26 & 3,52 & 3,26 & 3,47 \\
\hline & Experimental $-2^{2}$ & 3,3 & 3,46 & 3,38 & 3,55 & 3,53 & 3,56 & 3,83 \\
\hline & Control -IM-2 ${ }^{1}$ & 3,41 & 3,42 & 3,4 & 3,38 & 3,28 & 3,38 & 3,39 \\
\hline
\end{tabular}

Table 2. Numerical average value of assimilation on universities
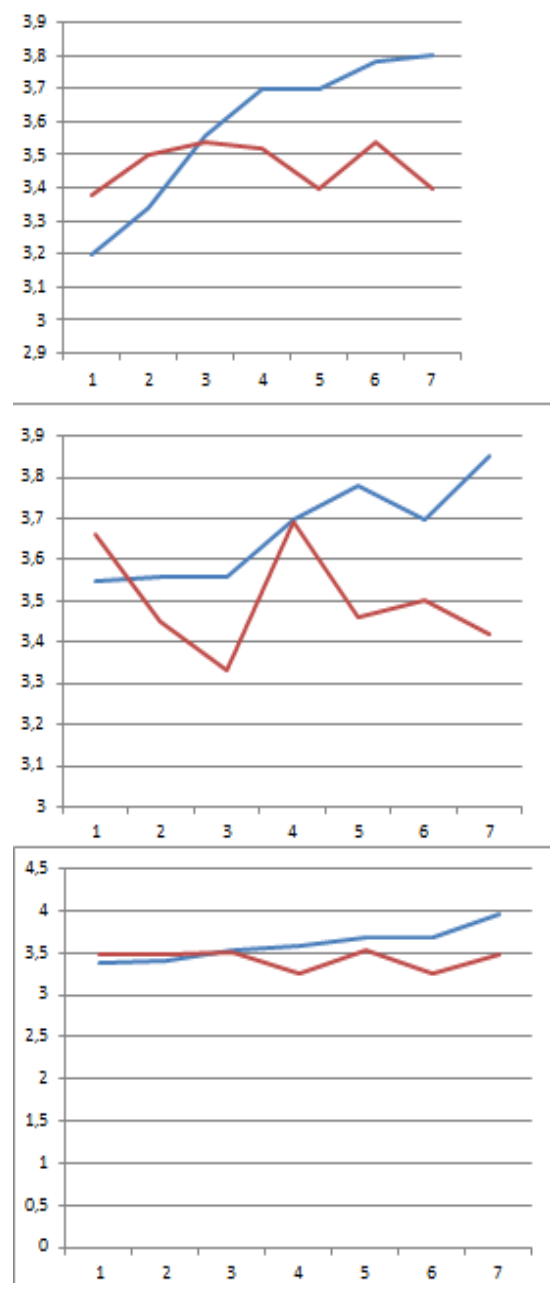
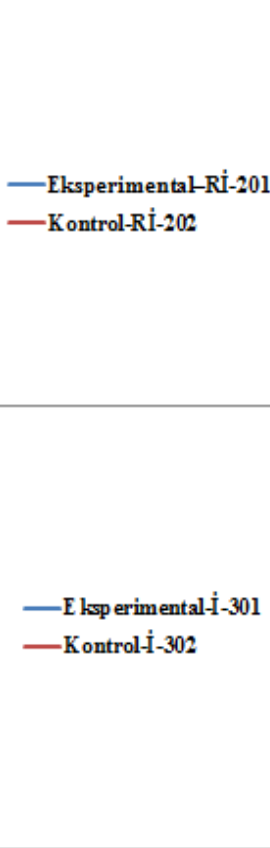

-E ssperimental-iM 1 -KontrolìM $1^{2}$

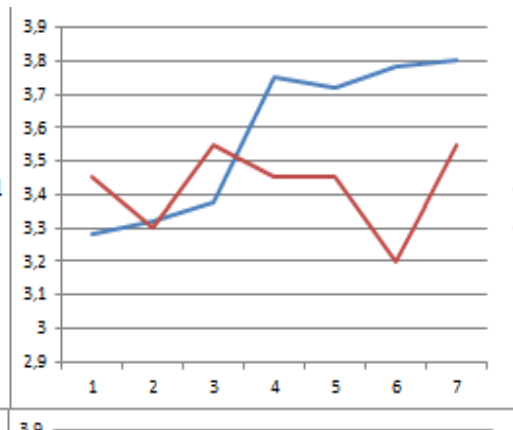

—Eksperimental-i-201 —Kontroli-202
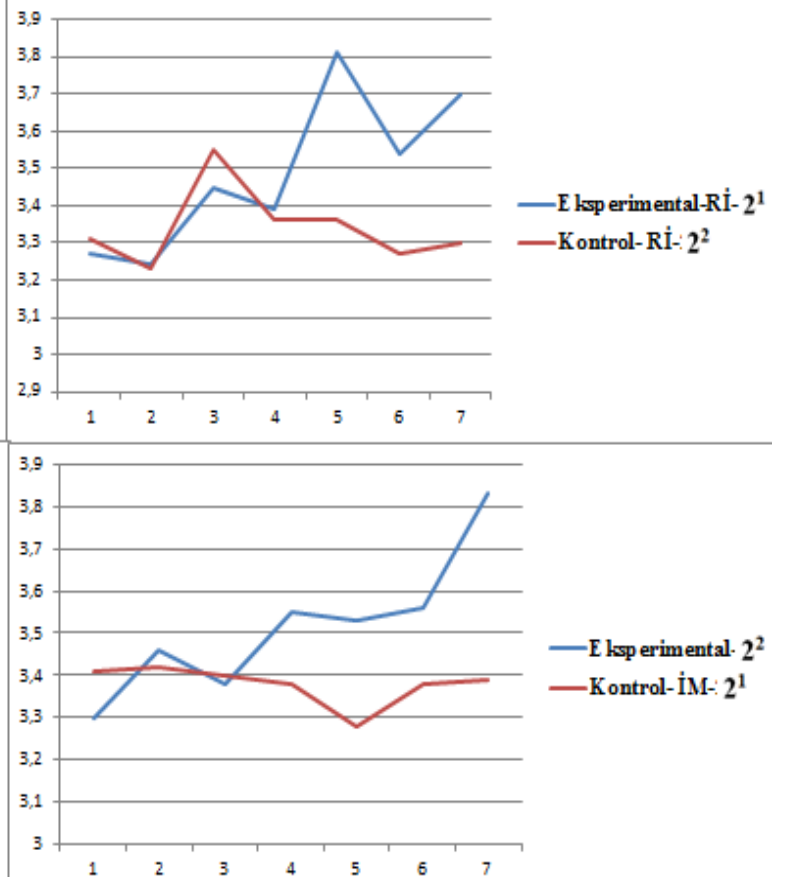

Figure 1. Diagram of numerical average value of assimilation on universities 
The average score for university degrees was calculated as follows:

$\mathrm{k}_{\mathrm{io}}$-numerical average score of the results of the experimental and control groups in the initial test;

$\mathrm{k}_{1 \mathrm{o}}$ - Quantitative average score of the results of experimental and control groups in the first test, etc.;

$\mathrm{k}_{\mathrm{yo}}=\left(\mathrm{R} 201 \mathrm{~K}_{\mathrm{y}}+\dot{\mathrm{I}} 201 \mathrm{~K}_{\mathrm{y}}+\dot{\mathrm{I}} 301 \mathrm{~K}_{\mathrm{y}}\right)$ : .

Here, $\mathrm{k}_{\mathrm{yo}}$ - the final numerical average for universities;

RI $201 K_{y}$ - average grade at the faculty, RI201 average grade in the group;

I $201 \mathrm{~K}_{\mathrm{y}}$ - average grade at the faculty, I201 - average grade in the group;

I $301 \mathrm{~K}_{\mathrm{y}}$ - average grade at the faculty, I301 - average grade in the group.

Table 3 shows that, in the context of the experiments conducted, the average statistical value of appropriation level in the R-201, 202 groups of the Azerbaijan State Pedagogical University ranges from 0,96 to 1,10 ; and in the Rİ-2 ${ }^{1}$, IM- $1^{2}$, IM- $2^{1}$ groups of the Ganja State University are rising from 0,97 to 1,11 .

\section{Conclusions and Recommendations}

The experiment also found:

- The solution to questions of mathematical content increases the responsibility of students and encourages them to take learning more seriously.

- Students are increasingly interested in subjects and are more likely to engage in programming.

- $\quad$ Students come prepared for each course, knowing that, as always, their knowledge will be quickly tested.
- The level of knowledge and skills of each student is informed about at all lessons, the overall dynamics of the group are monitored and assistance is provided.

- New topics are easier for students to understand than previous ones. This is due to the fact that they study the previous topics sequentially, since the connection is not broken and the shortcomings in their knowledge are gradually being eliminated. Thus, they are more willing to understand the following topics.

- In the learning process, students gain more knowledge, effectively using time, reducing students' free time in the classroom, and they are always active.

Thus, the analysis of the results of the experiment suggests that the use of creative tasks in enhancing students' competency in mathematics and computer science classes of R201, RI202, I-201, 202, and I-301, 302 groups has been successful. The findings can be effectively used for training pre-service and in-service teachers studying mathematics and computer science. In this regard, the training should focus on the multidisciplinary integration of mathematics with mathematical tasks, with the emphasis on developing the necessary knowledge and skills, creative thinking, and European creative thinking. To achieve this goal, it is necessary to select and solve mathematical problems of informational character so that pre-service and in-service teachers will benefit from the innovative activity.

The results show the validity of the hypothesis presented in the study, suggesting that the effectiveness of teaching would significantly increase if the teacher applied the concept of teaching computer science in other universities.

Table 3. Average statistic values of control groups

\begin{tabular}{|c|c|c|c|c|c|c|c|c|}
\hline & & $\mathrm{k}_{\mathrm{i}}$ & $\mathrm{k}_{1}$ & $\mathrm{k}_{2}$ & $\mathrm{k}_{3}$ & $\mathrm{k}_{4}$ & $\mathrm{k}_{5}$ & $\mathrm{k}_{\mathrm{y}}$ \\
\hline \multirow{3}{*}{ ASPU } & Rİ201 & 0,95 & 0,95 & 1,01 & 1,05 & 1,09 & 1,07 & 1,12 \\
\hline & İ201 & 0,95 & 1,01 & 0,95 & 1,09 & 1,08 & 1,18 & 1,07 \\
\hline & İ301 & 0,97 & 1,03 & 1,07 & 1,00 & 1,09 & 1,06 & 1,13 \\
\hline Average value & & 0,96 & 1,00 & 1,01 & 1,05 & 1,09 & 1,10 & 1,10 \\
\hline \multirow{3}{*}{ GSU } & $\mathrm{RI}-2^{1}$ & 0,99 & 1,00 & 0,97 & 1,01 & 1,13 & 1,08 & 1,12 \\
\hline & İM-1 ${ }^{2}$ & 0,95 & 1,01 & 0,95 & 1,09 & 1,08 & 1,18 & 1,07 \\
\hline & İM-2 ${ }^{1}$ & 0,97 & 1,03 & 1,07 & 1,00 & 1,09 & 1,06 & 1,13 \\
\hline Average value & & 0,97 & 1,01 & 1,00 & 1,03 & 1,10 & 1,11 & 1,11 \\
\hline
\end{tabular}




\section{Appreciation}

I would like to thank the faculty of Mathematics and Informatics of the Azerbaijan State Pedagogical University and Ganja State University, where the pedagogical experiment was conducted. In particular, I would like to express my deep gratitude to the teachers of the Department of Informatics and Computer Science of the ADPU and the teachers of the Department of Informatics of the State University.

\section{REFERENCES}

[1] M.A. Gasanova. Preferential Specialty Laboratory Workshops for Informational Competence Students. // Pedagogy and Psychology in the Modern World: Theoretical and Practical Reasoning. Moscow, No. 10 (28), 2019, p. 21-25.

[2] Mahmudzade R., Sadigov I., Isayeva N. Textbook of class VIII. Baku, 2015.

[3] Mahmudzade R., Sadigov I., Isayeva N. IX textbook of class I computer. Baku, 2015.

[4] Ministry of Education of the Republic of Azerbaijan, Ganja State University, curriculum.

[5] Hasanova M. The Use of Creative Tasks Developed in Excel Program for Increasing of Students' Competencies. // Journal of Humanitarian and Socio-Economic Sciences. No. 5 (16), 2019, Oxford, UK, p.17-26.
[6] Hasanova M. Realizing Positive Factors in Pedagogical Competences of Teachers in Azerbaijan Education. // Colloquium-journal, No. 5 (16), Warszawa, Polska, 2018, p.31-32.

[7] Turbina EP Theoretic aspects of pedagogical improvisation in the process of developing the textbooks. // Internet Magazine "education world" 2017, Volume 5, \# 2 http://mir-nauki.com/PDF/25PDMN217.pdf (Friendly Quotes).

[8] Hainovskaya AA. Professionalism and Communicative Competence of Students in Pedagogical Vocabulary [Text].

[9] Guzanov B. N., Pustovalova E. I., Vyuzuzova EV Samostochnical methods of shaping the competencies in the methods of the multivariate subsystems // Municipal observations: innovative experiment. 2016. - No. 3. - Q. 6572.

[10] Goryacheva MV Model of information competence in the process of self-auditing processes of students [Text] // Izvestiya RGPU im. A.I. Herzen. - 2008. - No. 30 (67). - S. $368-372$.

[11] Palangov A. GS, Gasimova AM From the experience of organizing informatics lessons. // Teacher Training Policy and Problems, International Symposium. ADPU, Baku-2013, p.176-178.

[12] Gasimova AM, Experience of using information and communication technologies in the modern education system. / Materials of the XVII Republican scientific conference of doctoral students and young researchers. Ministry of Education of the Republic of Azerbaijan, Baku, 2013, p.167-169.

[13] Adigozalov A.S. As a means of expanding teacher's functions in computer training // Adigozalov A.S. Musayeva Sh.A. - ICT in Education, -2013, No. 1, - p. 69-73. 